COMPETITOR: Jurnal Pendidikan Kepelatihan Olahraga

Volume 13 Number 1 Year 2021

e-ISSN: 2657-0734 \& p-ISSN: 2085-5389

This work is licensed under a Creative Commons Attribution 4.0 International License

\title{
Contribution of Leg Muscle Explosive Power and Hand-Eye Coordination Against Upper Serve Capability
}

\author{
Abdul Kholid ${ }^{1^{*}}$, Antony Wijaya ${ }^{2}$, Altaibi $^{3}$, Habibi Febrianto ${ }^{4}$, Nurmawati ${ }^{5}$ \\ 1,2,3,4,5 Pendidikan Olahraga dan Kesehatan/Faculty of Teacher Training and Education / \\ Pasir Pengaraian University/Riau/Indonesia \\ 1,2,3,4,5J1. Tuanku Tambusai, Kumu Desa Rambah,Pasir Pengaraian, Rambah Hilir, \\ Rokan Hulu Regency, Riau 28557. \\ 1abdulkholid031@gmail.com, ${ }^{2}$ antonywijaya0684@gmail.com, ${ }^{3}$ Altaibi1728@gmail.com, \\ ${ }^{4}$ having.bibi@gmail.com, ${ }^{5}$ www.yati998@gmail.com
}

Received: January 10, 2021; Reviewed: February 10, 2021; Accepted: February 20, 2021;

Published: February 28, 2021

\begin{abstract}
The problem in this study is the low service ability of students of SMP Negeri 5 Rambah Hilir, and it is suspected that the problem arises due to several factors such as the low level of leg muscle explosive power and eye-hand coordination. This study aims to determine whether there is a contribution of leg muscle explosive power and eye-hand coordination to the top service ability of extracurricular students at SMP Negeri 5 Rambah Hilir. This research is included in correlational research. The population in this study were all extracurricular students at SMP Negeri 5 Rambah Hilir, totaling 15 people. From the research results it is known that the correlation coefficient ritung $>$ rtabel (hypothesis is accepted) and the significant test coefficient of the variables $X_{1}-Y, X_{2}-Y$ and $X_{1} X_{2}$ to $Y$ obtained Fhitung $>$ Ftabel. The results of this study prove: (1) there is a contribution between the $X_{1}$ leg muscle explosive power variable to the upper service ability $(Y)$ of $55.8 \%$. (2) There is a contribution between the Eye-Hand Coordination variable $\left(X_{2}\right)$ to the Upper Service Capability (Y) of 66.2\%. (3) Contribution of Leg Muscle Explosive Power $\left(X_{1}\right)$ and Eye-Hand Coordination $\left(X_{2}\right)$ to Upper Service Ability $(Y)$ was $73.4 \%$.
\end{abstract}

Keywords: Leg Muscle Explosive Power; Hand-Eye Coordination; Upper Service.

\section{INTRODUCTION}

Sports and Health Physical Education is a subject given at a particular school level which is one part of overall education that prioritizes physical activity and fostering a healthy life for physical, mental, social and emotional growth and development in harmony, harmony and balance (Bismar \& Sahabuddin, 2019). Physical Education, Sports and Health are subjects that are always present at all levels of education, be it elementary, junior high or senior high school and equivalent.

One part of the implementation of physical education teaching and learning activities in schools can be carried out in formal and non-formal ways through the 
Contribution of Leg Muscle Explosive Power and Hand-Eye Coordination Against Upper Serve Capability

Abdul Kholid ${ }^{1 *}$, Antony Wijaya ${ }^{2}$, Altaibi $^{3}$, Habibi Febrianto ${ }^{4}$, Nurmawati

1abdulkholid031@gmail.com

Intracurricular and Extracurricular channels. To support sports achievement other than at school, it can also be through coaching students outside of school/extracurricular activities. Extracurricular is a process of activities carried out outside school hours. This activity is a form of training outside of school with the aim of deepening students' understanding and knowledge of various subjects, especially Physical Education, Sports and Health subjects. Students can choose the sport they like to channel their talents and interests in sports activities at school. This is in accordance with what is explained by the Law of the Republic of Indonesia No. 3 year 2005 Clouse 25 Subsection 4 concerning the National Sports System states that: "Fostering and development of educational sports are carried out by taking into account the potential, abilities, interests and talents of students as a whole, both through Intracurricular and Extracurricular activities."

Based on the explanation previously explained, extracurricular activities are activities that are mostly carried out by schools at this time, because the activities are very positive, especially these activities can help students solve problems in the academic field. One of the sports in extracurricular activities at school is volleyball. In general, volleyball is played in a field with a line length of 18 meters on the side, a field width of 9 meters and a line width of 3 meters. Yusmar (2017: 144) states that volleyball is a game that uses the ball to be bounced (volleyed) in the air back and forth over the net (net), with the intention of being able to drop the ball in the opponent's field in order to find victory. Volleyball or bouncing the ball into the air can use all members or parts of the body from toe to head with perfect reflection (Sahabuddin, 2020). Furthermore, Priyanto (2014) explained that in volleyball, there are basic principles that must be considered. The principle of the volleyball game is to play the ball with volleyed (hit with the Leg) and try to drop the ball into the opponent's field by crossing the ball over the net and keeping the ball from falling on its own field (Sahabuddin, 2018a). Based on these opinions, it can be concluded that the game of volleyball is a popular sports game using the ball to be bounced or volley over the net to get points and increase endurance. The volleyball game technique that must be owned by a volleyball player first includes serving, passing, smash, and blocking. The ability of a person or athlete in a competition or competition is basically determined by four factors, namely: (1) physical condition, (2) technique, (3) tactics, (4) mental (psychic) factors. One of the most influential techniques in playing volleyball is the top serve.

Syaleh (2017) Servis is a ball shot made from behind the end line of the playing field over the net to the opponent's area. Sara \& Mashud (2016) Servicing is an attempt to kill 
Contribution of Leg Muscle Explosive Power and Hand-Eye Coordination Against Upper Serve Capability

Abdul Kholid ${ }^{1 *}$, Antony Wijaya ${ }^{2}$, Altaibi ${ }^{3}$, Habibi Febrianto ${ }^{4}$, Nurmawati $^{5}$

1abdulkholid031@gmail.com

the opponent to get seeds, even in order to get the seeds (score), service is also one of the first types of attack. Based on these opinions, the authors conclude that the top serve is one of the first strokes to start a volleyball game which is done by standing behind the finish line and between side line extensions. Top service requires good hitting technique to kill the ball on the opponent's side (Sahabuddin, 2018b). Good service is service that immediately scores or cannot be accepted by your opponent. To produce a fast and hard service technique, of course it cannot be separated from several factors including power, coordination of hand movements against the ball being hit and the speed of hand motion when hitting the ball, of course explosive power and eye-hand coordination are important motor components in volleyball game. Hidayat (2018) explosive power is a person's ability to combine strength and maximum speed in carrying out activities. The component of the physical condition of power is one of the determining elements in achieving sports achievement. Muchlisa (2017) the explosive power of the leg muscles is the ability of a muscle or group of leg muscles to cope with load resistance or at high speed in one complete movement. Meanwhile, Syaifuddin in Zulkarnain (2016) stated that the explosive power of the leg muscles is the ability of the leg muscles to handle the load with a high contraction rate. Based on the explanation that has been described regarding the explosive power of the leg muscles, it can be concluded that the explosive power of the leg muscles is the result of the maximum muscle strength in the shortest possible time.

As a means of locomotion for the body, the muscles have fibers consisting of slow twitch fibers and fast twitch fibers. Fast muscle fibers are also called white muscle fibers while slow muscle fibers are called red muscle fibers. Stronger fast muscle fibers work anaerobically which causes reactions and contractions to also speed up. While slow muscle fibers are stronger to work aerobically, so that their reactions and contractions also become slow. The leg muscles consist of the muscles of the upper leg and the muscles of the lower leg, as described below:

Upper leg muscles; The upper leg muscles consist of three groups, namely: flexores, exteriosores, and adductores consisting of the triceps femoris and biceps femoris. This muscle is located at the limit of the groin to the knee joint (on the front and back). As shown in the image below: 


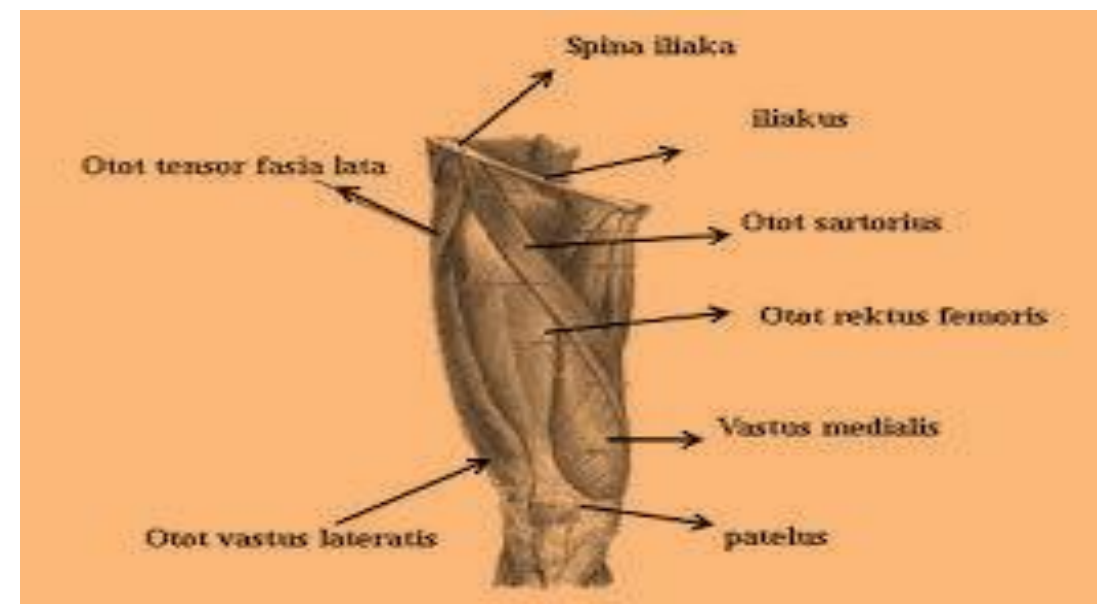

Image 1.

Upper leg muscles (Asy'ari, 2017)

Lower leg muscles; Lower leg muscles consist of three groups, namely: flexores, exteriosores, and muscle perenciators. These three muscles are located at the boundary of the lower knee. As seen in the image below:

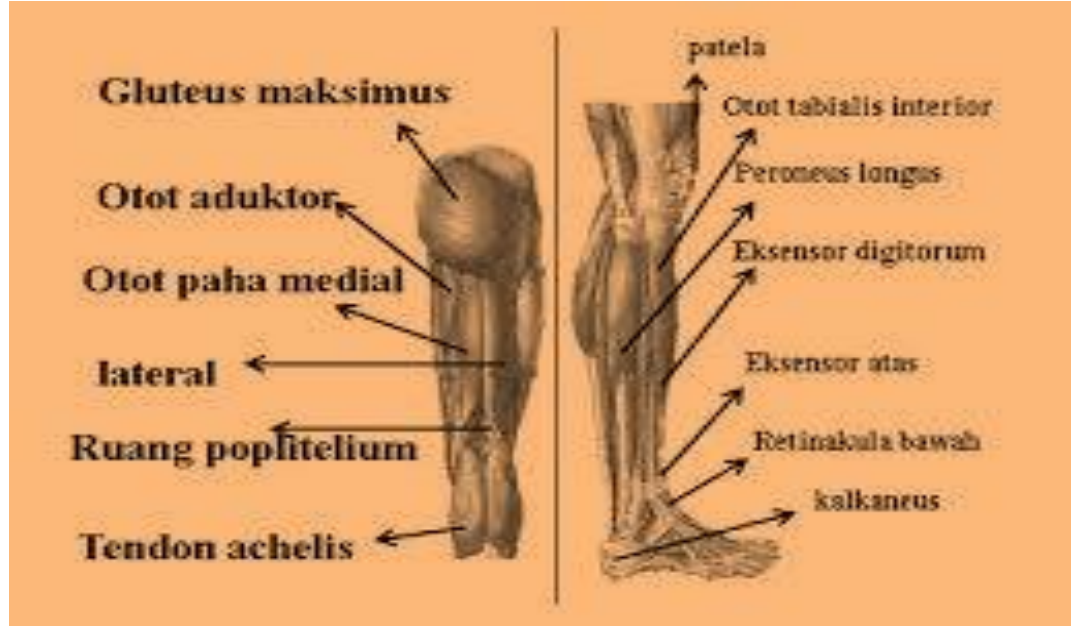

Image 2.

Lower leg muscles (Asy'ari, 2017)

Coordination is the ability to control body movements. A person is said to have good coordination if they are able to move easily and smoothly in a series of movements, their rhythm is well controlled and they are able to make efficient movements. According to Iskandar (2014) coordination is an adjustment that affects a group of muscles and during movements that give an indication of various skills. One of the determining factors for doing a volleyball smash is eye-hand coordination. Muchlisa (2017) eye-hand coordination has a significant relationship with the ability to serve accuracy for volleyball. Based on this opinion, it can be concluded that coordination is the ability to 
Contribution of Leg Muscle Explosive Power and Hand-Eye Coordination Against Upper Serve Capability

Abdul Kholid ${ }^{1 *}$, Antony Wijaya ${ }^{2}$, Altaibi ${ }^{3}$, Habibi Febrianto ${ }^{4}$, Nurmawati $^{5}$

1abdulkholid031@gmail.com

combine separate nervous systems of motion by turning them into an efficient movement pattern. The more complex a movement is, the higher the level of coordination.

The use of explosive power and eye-hand coordination together when serving volleyball requires a very fast time, so the time to swing the hand requires eye-hand coordination in the shortest possible time to hit the ball quickly and with direction. In line with that, the reality is happening in the field, especially for Volleyball Extracurricular Students at SMP Negeri 5 Rambah Hilir.

\section{METHOD}

This research is a correlational study which aims to determine the contribution between leg muscle explosive power and hand-eye coordination with the ability to serve volleyball in volleyball extracurricular students at SMP Negeri 5 Rambah Hilir. This study used 3 variables, consisting of 2 independent variables and 1 dependent variable. The independent variables are leg muscle explosive power (X1) and hand-eye coordination (X2), while the dependent variable is service ability (Y). The population in this study were volleyball Extracurricular Students at SMP Negeri 5 Rambah Hilir. After the author conducted a survey to the field and based on the information provided by the volleyball extracurricular coach at SMP Negeri 5 Rambah Hilir, the number of students who took part in the exercise was 15 people. Sampling in this study was carried out by total sampling technique. The test to collect leg muscle explosive power data is called the vertical jump test using a vertical jump board which aims to measure the leg muscles in jumping vertically (Prabowo, 2015). The assessment of each teste is given three repetitions, and then the highest jump of the three experiments will be taken as research data. This test to collect Eye-Hand Coordination data is called a catch ball that is reflected off the wall. The unit of this catch-ball throw test is the number of balls that enter the target from 10 throws (Ismaryati in Purwanto, 2014). Furthermore, to measure the Upper Service Ability in this study is to use the Service Test from the Center for Physical Fitness and Recreation of the National Department, Guidelines for Volleyball Skills Tests Ages 13-15 years in Purwanto (2014). The Top Service Test has a validity index of 0.676 and a reliability of 0.812 . The value taken is the sum of the total numbers of the six times $t$ service delivered by teste.

Based on the proposed hypothesis, the data analysis carried out can be stated as follows: 
Hypothesis one and hypothesis two were tested using the product moment correlation formula by Sugiyono (2016)

$$
r_{x y}=\frac{\mathrm{n} \sum \mathrm{X} \mathrm{Y}-\left(\sum \mathrm{X}\right)\left(\sum \mathrm{Y}\right)}{\left\{\mathrm{n} \sum \mathrm{X}^{2}-\left(\sum \mathrm{X}\right)^{2}\right\}\left\{\mathrm{n} \sum \mathrm{Y}^{2}-\left(\sum \mathrm{Y}\right)^{2}\right\}}
$$

Description:

Rxy : Correlation index number of $r$ product moment

$\sum \mathrm{x}:$ Total value of the data $\mathrm{x}$

$\sum \mathrm{y}:$ Total value of the data $\mathrm{y}$

$\mathrm{n} \quad$ : Lots of data

$\sum x y$ : The total of the products between the scores $\mathrm{x}$ and $\mathrm{y}$

Hypothesis three is tested using multiple correlation according to Sugiyono (2016).

$$
\operatorname{Ry} 12=\frac{\sqrt{\mathrm{r}^{2} \mathrm{y} 1+\mathrm{r}^{2} \mathrm{y} 2-2 \mathrm{ry}_{1} \mathrm{ry}_{2} \mathrm{r} 12}}{1-\left(\mathrm{r}^{2} 12\right)}
$$

Description:

Ry : Multiple correlation coefficient

$r_{y 1}:$ The correlation coefficient between $x_{1}$ and $y$

$r_{y_{2}}$ : Total of correlation coefficients $x_{2}$ and $y$

$r_{12}$ : Total of coefficients $x_{1}$ and $x_{2}$

Test the significance of the multiple correlation coefficient according to Sugiyono (2016).

$$
\mathrm{F}_{\text {hitung }}=\frac{R^{2} / k}{\left(1-R^{2}\right) /(n-k-1)}
$$

Description:

$\mathrm{R}$ : Multiple correlation coefficient

$\mathrm{k} \quad$ : A lot of independent variables

$\mathrm{n} \quad$ : A lot of sample members

\section{RESULTS AND DISCUSSION}

Research data, the score of Leg Muscle Explosive Power (X1) in this case the test measurement results using a vertical jump by conducting 3 experiments, where the highest value is used as data, for more details, the following results are obtained: the highest value (Max) is $67 \mathrm{~cm}$ and the lowest (Min) is $34 \mathrm{~cm}$, with an average (Mean) 47.33. The standard deviation (standard deviation) is 9.09. Furthermore, the distribution of the leg muscle explosive power category can be seen in Table 1 below: 
Tabel 1.

Distribution of Leg Muscles Explosive Power Variable Frequency (X1)

\begin{tabular}{cccc}
\hline No. & Interval Class & Frequency Absolute & Frequency Relative (\%) \\
\hline 1 & $34-41$ & 4 & 27 \\
2 & $42-48$ & 5 & 33 \\
3 & $49-55$ & 3 & 20 \\
4 & $56-62$ & 2 & 13 \\
5 & $63-69$ & 1 & 7 \\
\hline & Amount & $\mathbf{1 5}$ & $\mathbf{1 0 0}$ \\
\hline
\end{tabular}

Then Eye-Hand Coordination (X2) After 10 throws with one hand, then the right hand throws it and the left hand catches it. Also throwing 10 times, the ball must be thrown from below (undearm). For more details, the following results are obtained: the highest value (Max) is 17 and the lowest (Min) is 8, with an average (Mean) 13.00, the standard deviation (standard deviation) is 2.70. Furthermore, the distribution of eye-hand coordination categories can be seen in Table 2 below:

Tabel 2.

Distribution of Hand-Eye Coordination Variable Frequency (X2)

\begin{tabular}{cccc}
\hline No & Interval Class & Frequency Absolute & Frequency Relative (\%) \\
\hline 1 & $8-10$ & 2 & 13 \\
2 & $11-12$ & 5 & 33 \\
3 & $13-14$ & 3 & 20 \\
4 & $15-16$ & 3 & 20 \\
5 & $17-18$ & 2 & 13 \\
\hline & Amount & $\mathbf{1 5}$ & $\mathbf{1 0 0}$ \\
\hline
\end{tabular}

Then to measure the Upper Service Ability is to use the Service Test from the Center for Physical Fitness and Recreation of the National Department, Volleyball Skills Test Guide for ages 13-15 years. The purpose of this test is to measure the student's service ability and direct the target ball that has been provided. The result of this test is the number of scores obtained from 6 times the service depending on the ball falling into the target box on the field. For more details, the following results are obtained: the highest value (Max) of the Extracurricular Service Ability of SMP Negeri 5 Rambah Hilir students is 29 and the lowest (Min) is 14, with an average (Mean) 22.07, the standard deviation is 4.77 . 
Tabel 3.

Distribution of Upper Service Variable Frequency (Y)

\begin{tabular}{cccc}
\hline No & Interval Class & Frequency Absolute & Frequency Relative (\%) \\
\hline 1 & $14-17$ & 3 & 20 \\
2 & $18-20$ & 3 & 20 \\
3 & $21-23$ & 3 & 20 \\
4 & $24-26$ & 3 & 20 \\
5 & $27-29$ & 3 & 20 \\
\hline & Amount & 15 & 100 \\
\hline
\end{tabular}

The purpose of normality testing is to test the assumption that the data sampling distribution approaches or follows population normality. The normal sampling state is important, as it is a requirement of using statistics for hypothesis testing. The technique used in testing normality in this study is to use the Liliefors test.

Tabel 4.

Results of Normality Test Analysis

\begin{tabular}{llcccc}
\hline No & \multicolumn{1}{c}{ Variable } & $\mathbf{N}$ & $\mathbf{L}_{\text {observation }}$ & $\mathbf{L}_{\text {table }}$ & Description \\
\hline 1. & Leg Muscle Exlposive Power & 15 & 0,0969 & 0,2200 & Normal \\
2. & Eye-Hand Coordination & 15 & 0,1557 & 0,2200 & Normal \\
3. & Upper Servis Ability & 15 & 0,0980 & 0,2200 & Normal \\
\hline
\end{tabular}

In table 4 it can be seen that the leg muscle explosive power data (X1) obtained $\mathrm{L}_{\text {Observation }}=0.0969$ and from $\mathrm{L}_{\text {table }}=0.2200$ obtained a normal distribution because $\mathrm{L}_{\text {observations }}<\mathrm{L}_{\text {table }}$ or $0.0969<0.2200$ concluded that the data was normal. Data from the eye-hand coordination (X2) obtained by $\mathrm{L}_{\text {observation }}=0.15557$ and from $\mathrm{L}_{\text {table }}=0.2200$ obtained a normal distribution because $\mathrm{t}_{\text {observation }}<\mathrm{L}_{\text {table }}$ or $0.1557<0.2200$ concluded that the data was normal. And the data on the results of Upper Service Ability (Y) obtained $\mathrm{L}_{\text {observation }}=(0.0980)$ and from $\mathrm{L}_{\text {table }}=(0.2200)$ obtained a normal distribution population because $\mathrm{L}_{\text {observation }}<\mathrm{L}_{\text {table }}$ or $0.0980<0.2200$ concluded that the data was normal.

Based on the results of the meaningful correlation test between the Leg Muscle Explosive Power score (X1) on the Upper Service Ability (Y), the $\mathrm{t}_{\text {count }}$ value is 4.048, where the $t_{\text {count }}>t_{\text {table }}(4.048>1.771)$. Furthermore, to see the magnitude of the contribution of leg muscle explosive power to upper service ability, it is sought through the coefficient of determination, namely 0.747 , which means that leg muscle explosive 
Contribution of Leg Muscle Explosive Power and Hand-Eye Coordination Against Upper Serve Capability

Abdul Kholid ${ }^{1 *}$, Antony Wijaya ${ }^{2}$, Altaibi ${ }^{3}$, Habibi Febrianto ${ }^{4}$, Nurmawati $^{5}$

1abdulkholid031@gmail.com

power contributes $55.8 \%$ to the upper service ability. Based on the meaningful test of the correlation between the Eye-Hand Coordination score (X2) to the Top Service Ability $(Y)$, it is obtained that the tcount value is 4.048 , where the $t_{\text {count }}>t_{\text {table }}(5.041>1.771)$. Furthermore, to see how much Eye-Hand Coordination contributes to Upper Service Capability, the coefficient of determination obtained is 0.813 , which means that the EyeHand Coordination variable contributes $66.2 \%$ to the Upper Service Capability. The results of these calculations indicate that the multiple correlation analysis between the Explosive Power of the Leg Muscles and Eye-Hand Coordination together contributes to the Upper Service Ability. This can be seen from the value of $F_{\text {count }}>F_{\text {table }}(4,950>3,38)$. From the data above, it can be concluded that there is a significant relationship between leg muscle explosive power and hand-eye coordination on upper service ability.

\section{CONCLUSIONS AND SUGGESTIONS}

Based on the results of the analysis and discussion described in the previous section, in this chapter conclusions and suggestions can be drawn, namely as follows:

There is a significant contribution between the Explosive Power of the Legs Muscles to the upper servis Ability of Volleyball for Volleyball Extracurricular Students at SMP Negeri 5 Rambah Hilir with a percentage of 55.8\%.

There is a significant contribution between Eye-Hand Coordination to the upper servis Ability of Volleyball for Volleyball Extracurricular Students at SMP Negeri 5 Rambah Hilir with a percentage of $66.2 \%$.

There is a significant contribution between Leg Muscle Explosive Power and EyeHand Coordination on Volleyball upper servis Ability in Volleyball Extracurricular Students at SMP Negeri 5 Rambah Hilir with a percentage of $73.4 \%$.

\section{REFERENCES}

Asy'ari, A. F., Husin, S., \& Suranto, S. (2017). Hubungan Antara Panjang Tungkai Dan Power Tungkai Dengan Hasil Tendangan Dollyo Chagi. JUPE (Jurnal Penjaskesrek), 5(3).

Bismar, A. R., \& Sahabuddin, S. (2019). Studi Pelaksanaan Evaluasi Pembelajaran Pendidikan Jasmani Olahraga dan Kesehatan pada Siswa SMP di Makassar. Seminar Nasional $L P 2 M$ $U N M$, $O(0)$. https://www.ojs.unm.ac.id/semnaslemlit/article/view/8250

Hidayat, A. (2018). Pengaruh Daya Ledak Tungkai, Koordinasi Mata Kaki dan Keseimbangan Terhadap Kemampuan Shooting ke Gawang Pada Permainan 
Contribution of Leg Muscle Explosive Power and Hand-Eye Coordination Against Upper Serve Capability

Abdul Kholid ${ }^{1 *}$, Antony Wijaya ${ }^{2}$, Altaibi ${ }^{3}$, Habibi Febrianto ${ }^{4}$, Nurmawati ${ }^{5}$

1abdulkholid031@gmail.com

Sepakbola Siswa SMA Negeri 14 Sinjai. (Doctoral dissertation, Universitas Negeri Makassar).

Iskandar, I. (2016). Hubungan Koordinasi Mata-tangan dengan Servis Atas Bola Voli Mahasiswa Putra Penjaskes IKIP-PGRI Pontianak. Jurnal Pendidikan Olahraga, 3(2), 146-155.

Muchlisa, A. W. (2017). Pengaruh koordinasi mata-tangan, daya ledak otot tungkai dan motivasi berprestasi terhadap keterampilan smash. Jurnal Pendidikan Jasmani, 30.

Prabowo, A, D. (2015). Hubungan Daya Ledak Otot Tungkai Kekuatan Otot Lengan Dan Kelentukan Pergelangan Tangan Dengan Hasil Smash Norma. Skripsi: Universitas Negeri Semarang.

Priyanto, J., Hidayah, T., \& Nugroho, P. (2014). Model Pembinaan Prestasi Olahraga Voli Pantai di Kabupaten Indramayu Tahun 2013. Journal of Sport Sciences and Fitness, 3(1).

Purwanto, D. (2014). Hubungan Antara Kekuatan Otot Lengan Dan Koordinasi Mata Tangan Dengan Ketepatan Servis Atas Siswa Yang Mengikuti Ekstrakurikuler Bolavoli Di SMP Negeri 2 Miri. Skripsi: Universitas Negeri Yogyakarta.

Sahabuddin. (2018a). Keterampilan Teknik Dasar Bolavoli Pada Siswa Putra. SPORTIVE: Journal Of Physical Education, Sport and Recreation, 2(1), 59-62. https://doi.org/10.26858/sportive.v2i1.16846

Sahabuddin. (2018b). Pengaruh Latihan Model Pembelajaran Pukulan Bola Ke Tembok Terhadap Kemampuan Servis Atas Bolavoli Pada Siswa SMK Negeri 2 Makassar. Competitor: Jurnal Pendidikan Kepelatihan Olahraga, FIK UNM, 10(1), 28-36. https://doi.org/https://doi.org/10.26858/com.v10i1.8480

Sahabuddin. (2020). Ektifitas Kelentukan Pergelangan Tangan Dan Kekuatan Otot Lengan Dengan Kemampuan Servis Atas Bolavoli. SPORTIVE: Journal Of Physical Education, Sport and Recreation, 4(1), 23-32. https://doi.org/10.26858/sportive.v4i1.17168

Sara, I, A. dan Mashud (2016). Penerapan Pembelajaran Servis Atas Bolavoli Menggunakan Gaya Mengajar Inklusi Pada Siswa Kelas X Di SMK Grafika PGRI-Pakis. Jurnal Multilateral, Volume 15, No. 2.

Sugiyono, (2016). Metode penelitian kuantitatif R\&D Pendidikan. Bandung: Alfabeta.

Syaleh, M. (2017). Upaya Meningkatkan Hasil Belajar Servis Atas Bola Voli Melalui Media Pembelajaran Lempar Pukul Bola Kertas pada Siswa Kelas VII SMP. Jurnal Prestasi, 1(1).

Undang-Undang Republik Indonesia Nomor 3 Tahun 2005 Pasal 25 Ayat 4 Tentang Sistem Keolahragaan Nasional. 
Yusmar, A. (2017). Upaya Peningkatan Teknik Permainan Bola Voli melalui Modifikasi Permainan Siswa Kelas X SMA Negeri 2 Kampar. Jurnal PAJAR (Pendidikan Dan Pengajaran), 1(1), 143-152.

Zulkarnain, I., Yundarwati, S., \& Suriatno, A. (2016). Pengaruh Latihan Loncat Tali dan Lompat Kijang Terhadap Daya Ledak Otot Tungkai dalam Permainan Bola Voli pada Siswa Putra Kelas VII SMPN 1 Keruak Kabupaten Lombok Timur Tahun Pelajaran 2015/2016. Gelora: Jurnal Pendidikan Olahraga dan Kesehatan, 3(2), $453-465$ 